\title{
Phenotypic Expression, Stability, and Inheritance of a Recessive Resistance to Monopartite Begomoviruses Associated with Tomato Yellow Leaf Curl Disease in Tomato
}

\author{
E. García-Cano, R. O. Resende, L. S. Boiteux, L. B. Giordano, R. Fernández-Muñoz, and E. Moriones
}

First and sixth authors: Laboratorio de Virología Vegetal, Est. Exp. La Mayora, Consejo Superior de Investigaciones Científicas (CSIC), E29750 Algarrobo-Costa, Málaga, Spain; second author: Departamento de Biologia Celular, Universidade de Brasília (UnB), 70910-970 Brasília-DF, Brazil; third and fourth authors: Embrapa Vegetable Crops, National Center for Vegetable Crops Research (CNPH), CP 218, 70359-970 Brasília-DF, Brazil; and fifth autor: Departamento de Mejora Vegetal, Est. Exp. La Mayora, CSIC, E-29750 Algarrobo-Costa, Málaga, Spain.

Accepted for publication 23 January 2008.

\begin{abstract}
García-Cano, E., Resende, R. O., Boiteux, L. S., Giordano, L. B., Fernández-Muñoz, R., and Moriones, E. 2008. Phenotypic expression, stability, and inheritance of a recessive resistance to monopartite begomoviruses associated with tomato yellow leaf curl disease in tomato. Phytopathology 98:618-627.

Tomato-infecting begomoviruses comprise a complex of monopartite and bipartite virus species that cause severe yield and quality losses worldwide. Therefore, the availability of wide spectrum resistance for begomovirus control is desirable. However, limited sources of resistance are available. In this study, three tomato inbred lines with resistance to bipartite begomoviruses of Brazil were tested for resistance to monopartite begomoviruses associated with the tomato yellow leaf curl disease (TYLCD). Stable resistance to Tomato yellow leaf curl virus was observed either by inoculation with Bemisia tabaci or with Agrobacterium

plete absence of TYLCD symptoms and restricted virus accumulation. Further studies performed with the line '468-1-1-12' indicated that the resistance was also effective against three other virus species associated with TYLCD, indicating wide spectrum resistance of this source. Quantitative genetics analyses suggested that a major recessive locus with epistatic interactions is controlling the resistance to TYLCD in "468-1-112', which could facilitate introgression of this trait into elite tomato lines. The resistance was stable under field conditions with high TYLCD pressure. Mild symptoms could be observed in these conditions, and recovery from disease and from virus infection suggested an active host antiviral defense mechanism. The differential reaction of ' $468-1-1-12$ ' against a number of TYLCD-associated viruses and artificial chimeras between them allowed to identify a region of the virus genome that presumably contains a virus determinant for breaking the resistance to infection observed in '468-1-1-12'.
\end{abstract} tumefaciens using an infectious clone. The resistance resulted in a com-
During the past two decades, begomoviruses (genus Begomovirus, family Geminiviridae) have emerged worldwide following the spread of their insect vector, the whitefly Bemisia tabaci (Gennadius) (Hemiptera: Aleyrodidae). Diseases caused by these viruses have become the most economically important problem in tomato (Solanum lycopersicum L., syn. Lycopersicon esculentum Miller) in tropical and subtropical regions $(62,67,72)$. In the Old World, severe damage has been reported throughout the Mediterranean Basin, the Middle East, Africa, and Southeast Asia (14, 16,45). Similarly, in the New World losses have been reported in North America, the Caribbean, Central America, and a large portion of South America $(8,26,42,57,60)$.

Begomoviruses are plant viruses with single-stranded DNA genomes encapsidated within small twinned (geminate) icosahedral virions (68). Most begomoviruses have bipartite genomes comprising two circular DNA components of about 2,800 nucleotides (DNAs A and B). However, the most widespread and destructive begomoviruses in tomato are monopartite begomoviruses associated with tomato yellow leaf curl disease (TYLCD), among them Tomato yellow leaf curl virus (TYLCV) (45). At least nine different begomovirus species have been reported associated with TYLCD (20). The functions in the DNA B

Corresponding author: E. Moriones; E-mail address: moriones@eelm.csic.es

doi:10.1094/PHYTO-98-5-0618

(c) 2008 The American Phytopathological Society component of bipartite begomoviruses are present in proteins encoded in the genome of monopartite begomoviruses. The genome of monopartite TYLCD-associated begomoviruses resembles DNA A and encodes a replication-associated protein (Rep), the replication enhancer protein (REn), the transcriptional activator protein (TrAP), the coat protein $(\mathrm{CP})$, the V2 protein, and the $\mathrm{C} 4$ protein. Open reading frames (ORF) are organized bi-directionally, separated by an intergenic region (IR) that contains key elements for the replication and transcription of the viral genome, including the origin of replication (68).

Control of begomoviruses is difficult and is mainly based on the use of insecticides to reduce B. tabaci populations, although with limited success. Moreover, the intensive use of chemicals cause environmental damage and results in the development of pesticide resistance in the insect vector $(9,10,19,52)$. Therefore, as for other plant viruses, the use of host-plant resistance is the most desirable alternative. Much work has been done in searching for sources of begomovirus resistance in tomato, and resistance factors have been found that can reduce viral replication and local or systemic movement within plants $(32,41,52)$. Related to virus resistance, begomoviruses have been shown to be able to trigger gene silencing, a plant defense response to virus infection $(35,74)$ that can allow recovery from infection (13).

No resistance to TYLCD has been found in tomato (S. lycopersicum); therefore, intensive screenings for resistance have been conducted in tomato wild relatives $(32,51,52)$. Variable levels of resistance were localized in distinct wild species accessions (28, $34,53,55,73,75)$. Breeding programs have been based primarily on 
introgressing resistance to TYLCV into elite tomato germplasm. The most promising TYLCV resistance was derived from $S$. chilense 'LA1969' $(25,38,65,75)$ and it was found to be controlled by a single gene (named $T y-1$ ) and at least two modifier genes $(27,76)$. Currently, the dominant $T y-1$ gene is widely used in commercial hybrids (17). However, under high inoculum pressure, Ty- 1 resistance could be overcome $(38,52)$. Moreover, reports on its performance against bipartite begomoviruses are contradictory, with varying degrees of tolerance shown to Tomato mottle virus in Florida (66) and to bipartite begomoviruses present in Brazil $(7,37,65)$.

Tomato wild relatives have also been screened for resistance to bipartite begomoviruses with variable success $(56,59,66,69)$. In Brazil, where a complex of at least eight different bipartite begomoviruses severely limits tomato production $(26,43,60)$, varying degrees of resistance were detected in several accessions of a Solanum germplasm collection (65). The most promising source of wide-range resistance was identified in the tomato line 'TX 468-RG' derived from the commercial hybrid 'Tyking' (released by Royal Sluis, Enkhuizen, The Netherlands). 'Tyking' was reported as resistant to TYLCV but the original germplasm resistant source was not made public (34) nor is the genetics of resistance understood. The resistance of 'TX 468-RG' was expressed as a complete absence in viral symptoms with viral DNA barely detectable when tested with a range of bipartite begomoviruses (65). Inheritance studies indicated that a single recessive gene (locus) controlled the resistance to disease symptom expression with a contribution of more genes for virus accumulation control; this locus was tentatively named as $t \mathrm{~cm}-1$ (23).

Multiple begomovirus infections are common in many tomatogrowing regions worldwide. Therefore, breeding for wide spectrum begomovirus resistance is a challenge. Previous studies performed with the tomato line 'TX 468-RG' suggested a broad range of resistance to bipartite begomoviruses. Therefore, it would be of special interest to evaluate the response of 'TX 468RG'-related lines to monopartite begomoviruses associated with TYLCD. In this study we provide data about the phenotypic expression and stability of the resistance present in 'TX 468-RG'related lines and conducted inheritance studies. We found that the resistance is also effective against monopartite begomoviruses associated with TYLCD, supporting the usefulness of this resistance for broad range control of begomoviruses infecting tomato. Interestingly, differences of virus accumulation in resistant plants after inoculation with several TYLCD-associated viruses and artificial chimeras allowed us to identify a region of the virus genome that presumably contains a virus determinant for breaking the resistance to infection of the resistant tomato source.

\section{MATERIALS AND METHODS}

Plant materials. A 'Tyking'-derived F7 family segregating for resistance to Brazilian bipartite begomoviruses (no symptoms versus weak/mild symptoms) was subjected to whitefly inoculation with the bipartite begomovirus Tomato chlorotic mottle virus under greenhouse conditions in Brasilia (Brazil). A single plant displaying an immune-like response was selfed and its progeny was submitted to a new cycle of inoculation and selection. Thus, an F8 line ('468-1-1-12') and two '468-1-1-12'-derived F9 lines ('483-1-22' and '483-1-30'), whose progenies displayed stable resistance were finally selected for use in the present study. The line named as 'TX 468-RG', used for crossings in a previous study to describe the inheritance of resistance to Brazilian bipartite begomoviruses (23), was derived from a single plant selection within '468-1-1-12'. The open-pollinated tomato cultivars Ohio 8245 and Moneymaker, susceptible to begomoviruses, and the commercial tomato $\mathrm{F}_{1}$ hybrid 'Anastasia' (Seminis Vegetable Seeds Iberica, Almería, Spain), resistant to TYLCD, were used as controls in the experiments.
Inheritance study. The inheritance of TYLCV resistance in '468-1-1-12' was studied based on the analysis of generations derived from a cross between the resistant ('468-1-1-12') and susceptible ('Ohio 8245') parents. The generations consisted of the two parental lines, the $\mathrm{F}_{1}$ hybrid ('Ohio 8245' $\times$ '468-1-1-12'), the first backcross to the resistant parent $\left(\mathrm{F}_{1} \times\right.$ '468-1-1-12', $\left.\mathrm{BC}_{1} \mathrm{R}\right)$, the first backcross to the susceptible parent $\left(\mathrm{F}_{1} \times\right.$ 'Ohio $8245,, \mathrm{BC}_{1} \mathrm{~S}$ ), and the $\mathrm{F}_{2}$.

Virus isolates and infectious clones of chimeric viruses. Infectious clones of monopartite begomoviruses associated with TYLCD, TYLCV-IL[ES:Alm:Pep:99], TYLCV-Mld[ES:72:97], TYLCSV-ES[ES:Mur1:92], Tomato yellow leaf curl Axarquia virus (TYLCAxV)[ES:Alg:00], and Tomato yellow leaf curl Málaga virus (TYLCMalV)[ES:421:99] have been described elsewhere $(22,40,44,46,49)$. Isolates of the Mld and IL strains of TYLCV differ genetically (47) and biologically based on symptoms induced in some tomato varieties (2). Infectious clones of chimeric viruses Q1 and Q5 artificially constructed by genetic exchange between TYLCV-Mld[ES:72:97] and TYLCSVES[ES:Mur1:92] have been described elsewhere (63). Briefly, Q1 and Q5 consist of TYLCSV-ES[ES:Mur1:92] in which the V2 and CP ORFs (Q1) or the IR region and the 5' two thirds of the Rep ORF (which includes the C4 ORF) (Q5) have been replaced with the corresponding fragments of TYLCV-Mld[ES:72:97].

Virus inoculation. B. tabaci-mediated inoculation was performed as described (40), using 25 viruliferous whiteflies per test plant. Nonviruliferous $B$. tabaci biotype Q individuals were obtained from a colony reared on melon (Cucumis melo L. cv. ANC42, Est. Exp. La Mayora germplasm collection). Viruliferous whiteflies were obtained by giving $B$. tabaci adults a $24 \mathrm{~h}$ acquisition access period (AAP) on systemically infected young leaves of tomato cultivar Moneymaker plants agroinoculated 3 weeks before. After the AAP, whiteflies were transferred to healthy test plants (three leaf growth stage) for a $48 \mathrm{~h}$ inoculation access period (IAP), using clip-on cages. After the IAP, insects were removed from plants which were treated with insecticide. Inoculation with infectious clones of TYLCD-associated viruses was performed by means of Agrobacterium tumefaciens-mediated inoculation (agroinoculation) with the stem puncture method described by Monci et al. (40). Tomato plants were inoculated at the three-leaf growth stage. After inoculation, plants were maintained in a growth chamber $\left(25^{\circ} \mathrm{C}\right.$ day and $20^{\circ} \mathrm{C}$ night, $70 \%$ relative humidity, with a $16 \mathrm{~h}$ photoperiod at $250 \mu \mathrm{mol} \mathrm{s} \mathrm{s}^{-1} \mathrm{~m}^{-2}$ photosynthetically active radiation) or in an insect-proof glasshouse with temperature control $\left(22\right.$ to $27^{\circ} \mathrm{C}$ day and 17 to $20^{\circ} \mathrm{C}$ night) and light supplementation when necessary.

Resistance evaluation and virus detection. The youngest newly emerged leaf of inoculated test plants was analyzed for virus infection. Freshly cross-sectioned petioles were squash-blotted on positively charged nylon membranes (Roche Diagnostics, Mannheim, Germany). Tissue blots were analyzed by hybridization using a digoxigenin (DIG)-labeled DNA probe able to detect the viruses associated with TYLCD in the Mediterranean basin, according to Accotto et al. (1). Tissue-blotting is not a quantitative technique to determine virus accumulation, but was demonstrated to be useful in differentiating relative viral susceptibility among materials with different levels of resistance (54). Therefore, when needed, an indirect estimation of the virus infection level present in infected plants was obtained from the intensity of the hybridization signal of tissue blots. For this, an arbitrary rating scale from 0 (no hybridization signal) to 5 (maximum hybridization intensity observed in susceptible control plants) was used. Membranes also were evaluated for nucleic acids load in tissue blots by subsequent hybridization with a probe to the $18 \mathrm{~S}$ rRNA gene (64).

TYLCD symptoms were evaluated in test plants according to a symptom severity rating scale varying from 0 (no symptoms) to 5 (severest symptoms) (31). 
Field trial. Performance of lines '468-1-1-12', '483-1-22', and '483-1-30' under natural TYLCD infection conditions was evaluated in a field trial conducted during the summer of 2004 in a plastic-house with widely open lateral windows at Est. Exp. La Mayora. Extremely high TYLCD pressure occurred during this trial and no other virus infection was detected. 'Moneymaker' was used as susceptible tomato control. Healthy tomato seedlings were grown in an insect-proof glasshouse, and plants of each of the four tomato genotypes tested were then transplanted in the field at the four-leaf growth stage in four parallel rows, with five plants per row. The within-row and between-row spacing was 0.6 and $1.5 \mathrm{~m}$, respectively. Each group of four rows served as a replicate, and a total of four replicates were planted. No insecticide treatment was done during the field trial in order to favor virus infection. TYLCD symptom development and virus infection were monitored weekly from the third to eighth week after transplant, in all the plants of each replicate by plant observation and tissue blot hybridization, respectively, and rated following the scales indicated above.

Data analysis. Infection efficiency of different viruses was compared under a generalized linear mixed model analysis (Logit as the link function and Binomial as the underlying distribution) by least-squares (LS) means tests by using the Statistical Analysis System for Windows, version 8.2 (SAS Institute, Cary, NC). The progression of symptom severity and virus accumulation ratings in plants of the field trial were compared between genotypes by LS means tests performed under a generalized linear mixed model analysis (Identity as the link function and Poisson as the underlying distribution) with Genotype as the classification variable and Week of monitoring as a covariate. Separate generalized linear model analyses for each genotype and LS means comparisons were performed to test differences between Weeks. Independence of the traits describing resistance response in the generations derived from the cross 'Ohio $8245^{\prime} \times$ '468-1-1-12' was studied using nonparametric Spearman's rank correlation coefficient $(\rho)$ and chi-square tests based on contingency tables analysis, calculated for the segregating populations using the statistical software SPSS for Windows, version 14.0 (SPSS Inc., Chicago, IL). Study of segregation for resistance in a Mendelian approach was done by grouping plants into resistant and susceptible classes. Segregation ratios were tested for goodness-of-fit to theoretical ratios for the hypotheses that either a single locus or two loci with recessive alleles control the resistance. Chi-square $\left(\chi^{2}\right)$ tests were performed on the segregating populations using numerical data. The study of inheritance of resistance based on a quantitative genetics approach was done considering a number of methods applied to data of both symptom and virus accumulation ratings. Testing of implication of a major locus controlling resistance was based upon the shape of the distributions of segregating generations for the two traits (symptom severity and virus accumulation ratings). The coefficient of bimodality $b=$ $\left(m_{3}^{2}+1\right) /\left[m_{4}+\left(3(n-1)^{2}\right) /((n-2)(n-3))\right]$, where $m_{3}=$ skewness, $m_{4}=$ kurtosis, and $n=$ number of observations, was calculated (SAS Institute). Departure from uniform and normal frequency distributions was tested by the Kolmogorov-Smirnov test (SPSS Inc.). Evidence of contribution of a major locus was only considered if distributions of segregating generations showed coefficients of bimodality higher than the corresponding to the uniform distribution $(b=0.555)$ and departed from both uniform and normal distributions. Minimum number of genes controlling resistance was estimated by the Wright's minimum effective factors calculated with $\mathrm{F}_{2}$ generation data by the Bjarko and Line (6) modification, and their errors estimated following Lande (30). Estimation of gene effects in the six-generation family was performed by the methods described by Mather and Jinks (36) using a self-made Excel sheet. The mid-parent value $m$ together with additive $(d)$ and dominance $(h)$ gene effects were estimated. The adequacy of such $m d h$ additive-dominance model was tested by $A B C$ scaling tests. For those cases in which any of the three scaling tests was significant, the following models of gene effects including additive $\times$ additive $(i)$, additive $\times$ dominance $(j)$, and dominance $\times$ dominance $(l)$ terms of digenic epistatic interactions were then calculated: $m d h i, m d h j, m d h l, m d h i j$, and $m d h i l$. No degree of freedom is left in the six-parameter mdhijl model and therefore it was not calculated. The best-fit model was chosen as that in which expected means deviated least from the observed means of the generations as indicated by a higher probability associated with the corresponding $\chi^{2}$ test. Broad-sense heritability $\left(H^{2}\right)$ on a single-plant basis was estimated following RodríguezHerrera et al. (61).

\section{RESULTS}

Effectiveness of resistance to TYLCD. Tomato lines '468-11-12', '483-1-22', and '483-1-30', exhibited a similar resistance response after inoculation with TYLCV-IL under glasshouse conditions during autumn either using whitefly-mediated or A. tumefaciens-mediated inoculation. Therefore, both inoculation methods were equivalent. In either case, no TYLCD symptoms were observed in any of the inoculated plants from lines ' $468-1-1$ 12', '483-1-22', and '483-1-30' even at 45 days postinoculation (dpi), whereas all inoculated plants of the susceptible control 'Moneymaker' exhibited severe TYLCD symptoms (Table 1). Similar results were also obtained for A. tumefaciens-mediated inoculations performed during winter or spring conditions. Although at lower hybridization intensity levels, analysis of virus presence indicated that TYLCV-IL could be detected in a number of '468-1-1-12', '483-1-22', and '483-1-30' inoculated plants (Fig. 1 and Table 1). However, differences to virus susceptibility seemed to exist depending on the environment conditions. Thus, except for one plant, absence of virus detection was observed during winter inoculations in test lines (Fig. 1), whereas virus

TABLE 1. Response of '483-1-22', '483-1-30', and '468-1-1-12' tomato breeding lines to inoculation with Tomato yellow leaf curl virus (TYLCV)

\begin{tabular}{|c|c|c|c|c|c|}
\hline \multirow[b]{2}{*}{ Type and season of inoculation ${ }^{\mathrm{a}}$} & \multirow{2}{*}{$\begin{array}{l}\text { No. of plants } \\
\text { inoculated }\end{array}$} & \multicolumn{4}{|c|}{ No. of symptomatic plants/no. of infected plants ${ }^{b}$} \\
\hline & & Moneymaker & $483-1-22$ & $483-1-30$ & $468-1-1-12$ \\
\hline \multicolumn{6}{|l|}{ Bemisia tabaci-mediated } \\
\hline Autumn & 10 & $10 / 10$ & $0 / 5$ & $0 / 5$ & $0 / 7$ \\
\hline Autumn & 10 & $10 / 10$ & $0 / 6$ & $0 / 6$ & $0 / 6$ \\
\hline Winter & 10 & $9 / 9^{c}$ & $0 / 1$ & $0 / 0$ & $0 / 0$ \\
\hline Spring & 10 & $9 / 9^{c}$ & $0 / 6$ & $0 / 5$ & $0 / 7$ \\
\hline \multicolumn{6}{|c|}{$\begin{array}{l}\text { Plants were inoculated at the three leaf growth stage with TYLCV-IL[ES:Alm:Pep:99] via B. tabaci using } 25 \text { viruliferous adult individuals per plant with a clip- } \\
\text { on cage, or via A. tumefaciens-mediated inoculation by stem injection with a culture of an infectious clone (provided by E. R. Bejarano, Universidad de Málaga, } \\
\text { Spain). Tomato 'Moneymaker' was used as susceptible control. }\end{array}$} \\
\hline
\end{tabular}


readily accumulated in plants of the control tomato 'Moneymaker' independently of the environmental conditions. Therefore, '468-1-1-12', '483-1-22', and '483-1-30', exhibited resistance to TYLCD but were not immune to TYLCV-IL infection. As similar results were obtained for all three lines, only line '468-1-1-12' was used in most of the subsequent studies.

Range of TYLCD-associated virus resistance in the line '468-1-1-12'. Similar to TYLCV-IL, four other TYLCD-associated viruses (TYLCV-Mld, TYLCSV-ES, TYLCMalV, and TYLCAxV) tested by agroinoculation were unable to induce symptoms in '468-1-1-12' plants. Also, lower levels of virus were detected under conditions tested, comparable to those observed in plants of a commercial tomato hybrid resistant to TYLCD ('Anastasia') (Fig. 2A). In contrast, severe TYLCD symptoms were observed for all viruses in 'Moneymaker' control plants except for TYLCMalV that exhibited more attenuated symptoms, as already reported (40). Therefore, '468-1-1-12' exhibited a wide range resistance to all the TYLCD-associated viruses reported in the Mediterranean basin.

Results shown in Figure 2 seemed to suggest that in contrast to that observed for 'Moneymaker', the ability of TYLCD-associated viruses to infect '468-1-1-12' plants varied. Thus, for example, TYLCSV-ES infected more '468-1-1-12' plants than TYLCV-Mld (Fig. 2B). Therefore, this aspect was further studied by agroinoculating TYLCSV-ES and TYLCV-Mld along with artificially constructed chimeric viruses (Q1 and Q5) (Fig. 3A).
Again, more efficient infection of '468-1-1-12' plants was observed for TYLCSV-ES than for TYLCV-Mld, and similar differences were also observed between Q1 and Q5 (Fig. 3B). Pooled data from Figures 2 and $3 \mathrm{~B}$ indicated that differences in the number of '468-1-1-12' plants infected are supported statistically $(P=0.0051$ for TYLCSV-ES versus TYLCV-Mld; $P=0.0271$ for $\mathrm{Q} 1$ versus Q5). Comparison of the performance of each virus type with its genetic composition suggested that the region comprising the IR and the $5^{\prime}$ two thirds of the Rep ORF which includes the C4 ORF contains a virus determinant that allows TYLCV-ES to infect '468-1-1-12' more efficiently than TYLCV-Mld.

Field resistance to TYLCD. Tomato breeding lines '468-1-112', '483-1-22', and '483-1-30', were tested for resistance to TYLCD under natural infection conditions. In a field trial conducted in Málaga (southern Mediterranean coast of Spain) under high TYLCD pressure, equivalent results were obtained for all three lines. Notably, in contrast to that observed during experimental inoculations, under the high disease pressure conditions, TYLCD symptoms could be observed in '468-1-1-20', '483-122', and '483-1-30' plants. However, symptoms were less severe than those observed in the susceptible control. Also, a progressive recovery from TYLCD symptoms and from virus accumulation occurred in plants of the breeding lines. As exemplified in Figure 4 for line '468-1-1-12', significant differences (LS means test, $P<0.0001)$ were observed between the breeding line and the susceptible control 'Moneymaker' in the evolution of either symp-

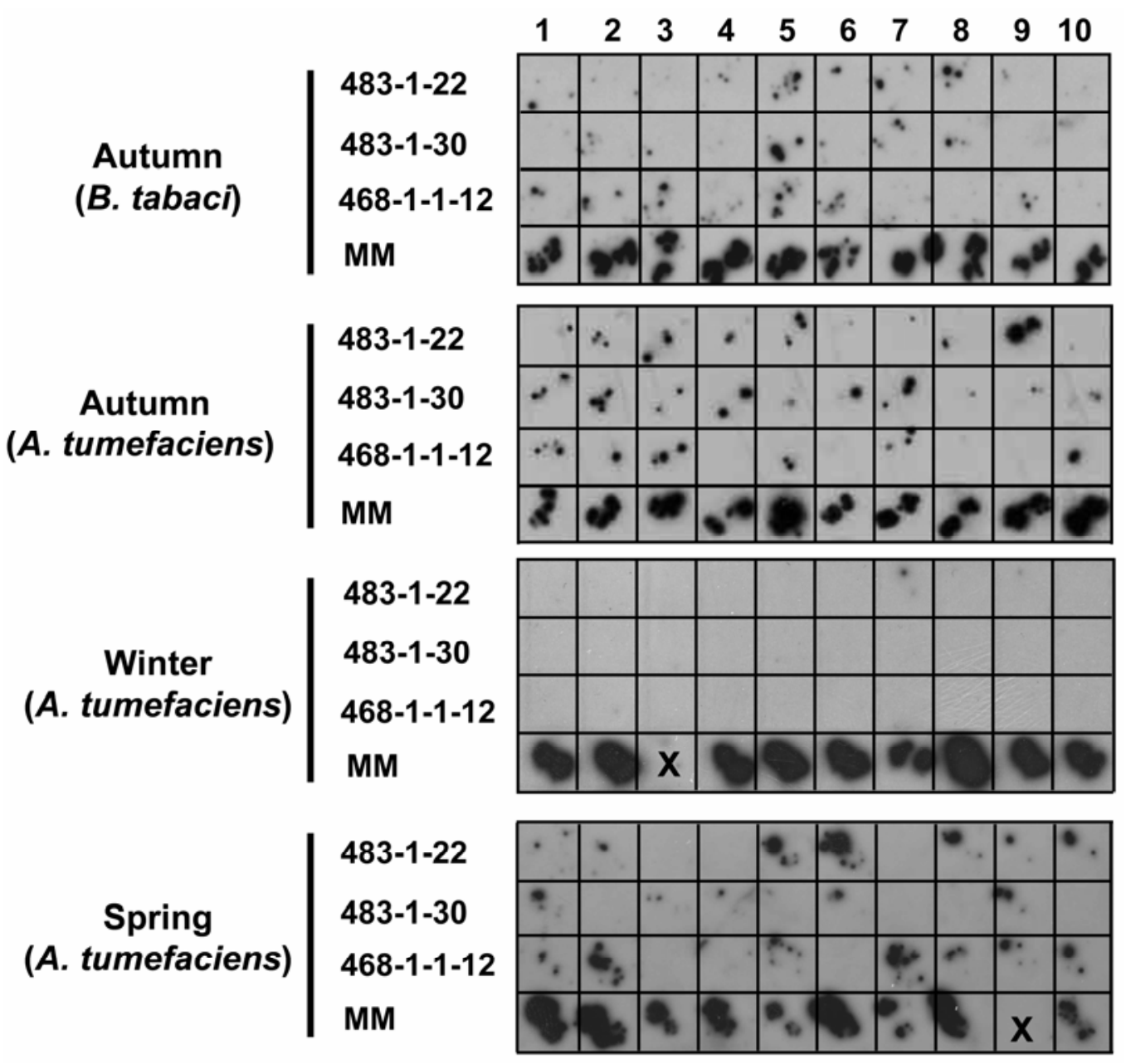

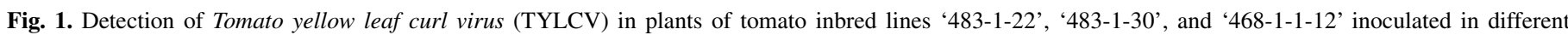
seasons under greenhouse conditions. Plants were inoculated with the isolate [ES:Alm:Pep:99] of TYLCV-IL either using Bemisia tabaci viruliferous individuals or by Agrobacterium tumefaciens-mediated inoculation using an infectious clone. Plants were analyzed at 45 days postinoculation for virus presence by hybridization of tissue blots of petiole cross sections of newly emerged young leaves performed on positively charged nylon membranes (two prints per sample were performed in each individual square). Tomato 'Moneymaker' (MM) was included as susceptible control. Plant number is indicated at the top of the figure. X, means no plant present. 
tom severity or the intensity of hybridization signals observed in plants. Severe TYLCD symptoms were observed in plants of the susceptible control from the fourth week after transplant whereas '468-1-1-12' plants exhibited milder symptoms that progressively decreased with time, being hardly visible at the eighth week after transplant (Fig. 4). A similar situation was observed for results of hybridization. Thus, LS means comparisons between data for weeks 4 and 8 were not significant for 'Moneymaker' $(P=0.887$ for symptoms severity and $P=0.678$ for hybridization signal) but highly significant for '468-1-1-12' $(P<0.0001$ for symptoms severity and for hybridization signal), supporting our observation that '468-1-1-12' recovered from the disease. Equivalent results were obtained for lines '483-1-22' and '483-1-30'.

Inheritance of resistance to TYLCV in '468-1-1-12'. The study of the mode of inheritance of the TYLCD resistance in '468-1-1-12' was conducted with the family of generations of the
'Ohio 8245 ' $\times$ '468-1-1-12' cross, after agroinoculation with an isolate of TYLCV-IL under controlled conditions in a growth chamber. In these conditions, clear differences were observed between plants of '468-1-1-12' and of the susceptible parent at 15 dpi for virus infection based on hybridization of tissue blots, and at 30 dpi for the severity of TYLCD symptom induced by TYLCV-IL. Thus, the plants of the resistant '468-1-1-12' parent exhibited no symptoms and showed low signal intensity in hybridization analyses. In contrast, plants of the susceptible 'Ohio 8245 ' parent showed both severe symptoms and strong intensity of hybridization signals. $F_{1}$ plants showed variability in symptom expression and in hybridization signals. Results of the backcrosses indicated recessive resistance since all $\mathrm{BC}_{1} \mathrm{~S}$ plants showed strong symptoms and intensity of hybridization signals, while $\mathrm{BC}_{1} \mathrm{R}$ plants segregated for both traits. $\mathrm{F}_{2}$ plants also segregated for symptoms and hybridization signals. In the segre-

A

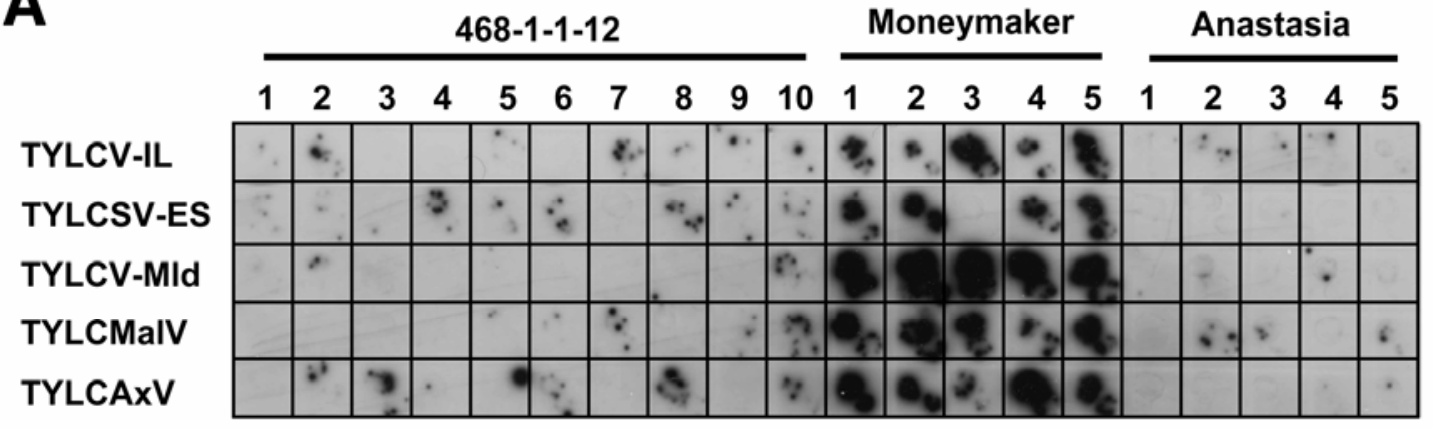

B

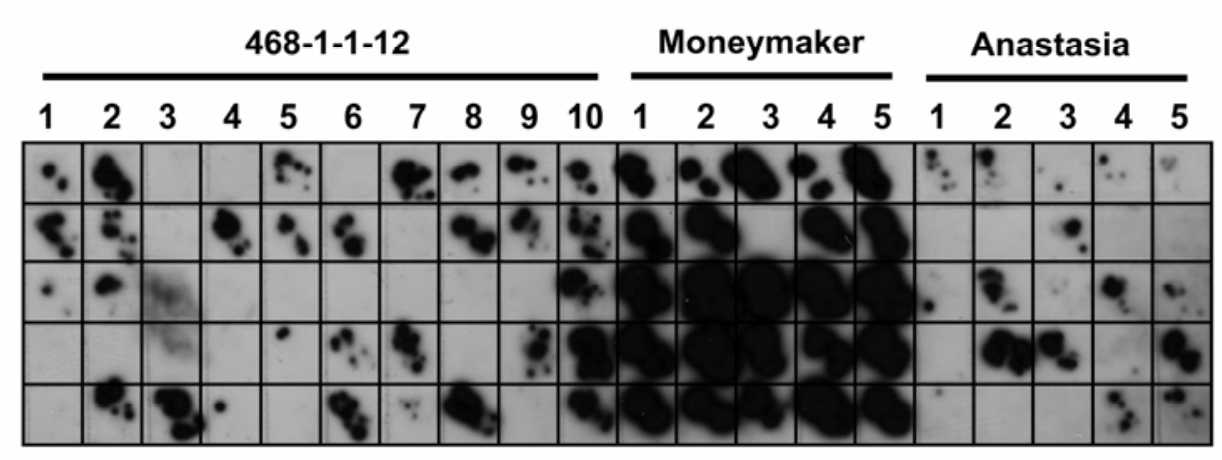

C

TYLCV-IL

TYLCSV-ES

TYLCV-MId

TYLCMaIV

TYLCAXV

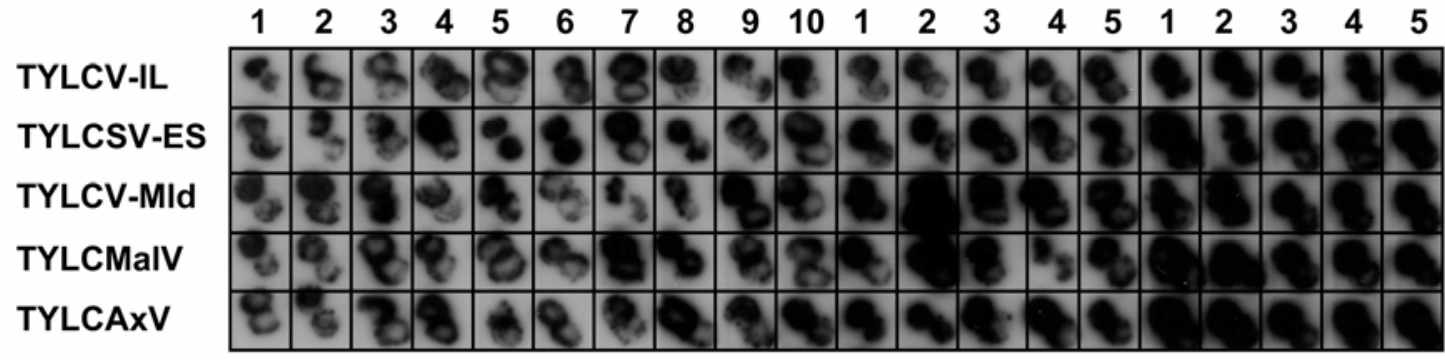

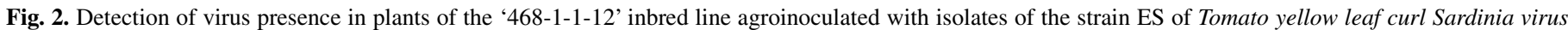

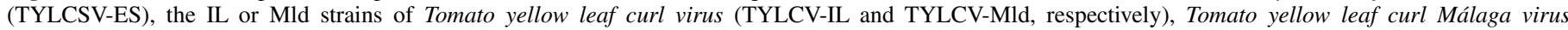

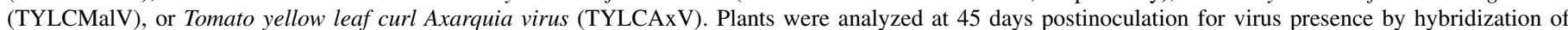

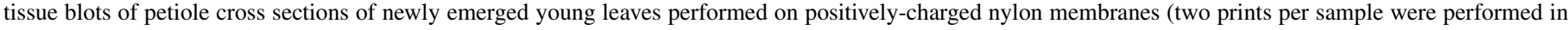

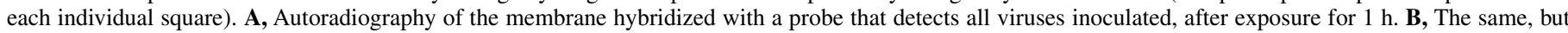

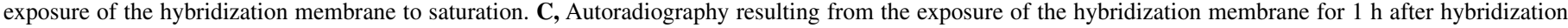

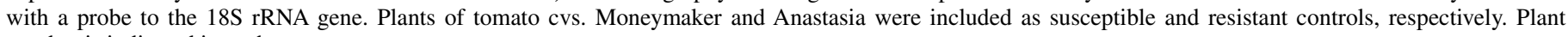
number is indicated in each case. 
gating generations, levels of TYLCD symptoms and intensity of hybridization signal correlated significantly $(\rho=0.566, P<$ 0.0001 for $\mathrm{BC}_{1} \mathrm{R} ; \rho=0.514, P<0.0001$ for $\left.\mathrm{F}_{2}\right)$. For each trait, plants were classified as resistant or susceptible in function of exhibiting behavior similar to that of the corresponding parent. Contingency table analysis revealed that symptom expression and level of virus accumulation estimated from intensity of hybridization signals were not independent $\left(\chi^{2}=49.93, P<0.0001\right.$ for $\mathrm{BC}_{1} \mathrm{R} ; \chi^{2}=68.87, P<0.0001$ for $\mathrm{F}_{2}$ ) suggesting a common genetic control of both traits. Thereby, genetical analysis in a qualitative Mendelian approach was attempted using the betweenparents most contrasting trait, symptom expression. The two phenotypic classes were resistant (symptom rate 0) and susceptible (symptom rate 1 to 5). As shown in Table 2, based on the number of resistant (39 in the $\mathrm{BC}_{1} \mathrm{R}$ and 67 in the $\mathrm{F}_{2}$ ) and susceptible (66 in the $\mathrm{BC}_{1} \mathrm{R}$ and 155 in the $\mathrm{F}_{2}$ ) plants, the model for a single recessive gene controlling the resistance could be supported although at a low probability level $(P=0.075)$ by $\mathrm{F}_{2}$ segregation but not by segregation of $\mathrm{BC}_{1} \mathrm{R}$. It was not possible to fit the two-recessive genes model for either segregating generation.

Because of the unclear qualitative genetic analysis and the unexpected $F_{1}$ variability, rates of TYLCD symptoms and virus accumulation (estimated from symptom and intensity of hybridization signal ratings, respectively) were analyzed using methods of quantitative genetics. Bimodality of $B_{1} R$ and $F_{2}$ frequency distributions was supported by deduced values of coefficients of bimodality (symptoms: $b=0.634$ for $\mathrm{BC}_{1} \mathrm{R}$ and $b=0.775$ for $\mathrm{F}_{2}$;
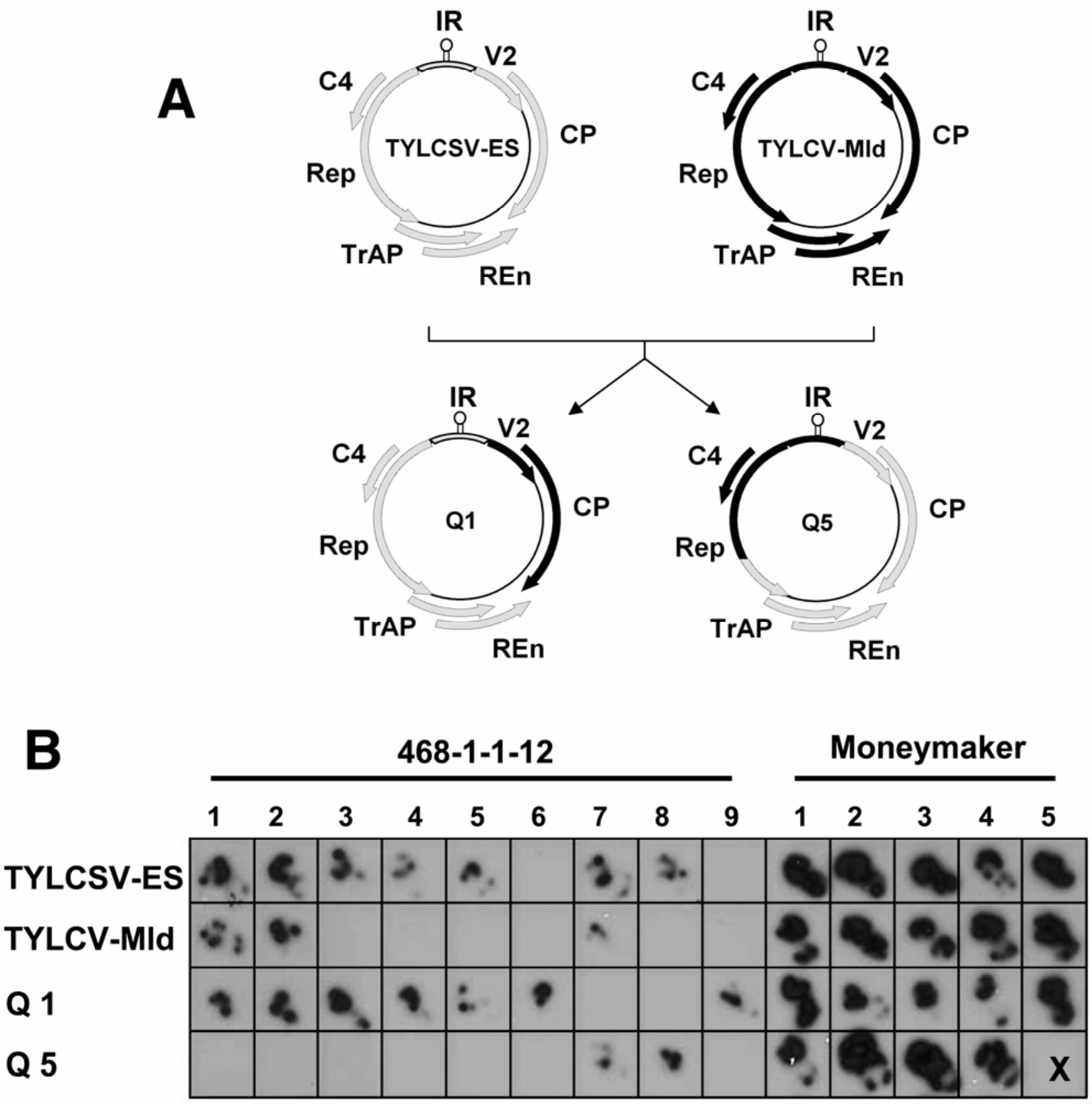

Fig. 3. Detection of virus presence in plants of the '468-1-1-12' inbred line agroinoculated with isolates of the strain ES of Tomato yellow leaf curl Sardinia virus (TYLCSV-ES), the Mld strains of Tomato yellow leaf curl virus (TYLCV-Mld), or with artificially constructed chimeric viruses Q1 and Q5. A, Schematic representation of regions involved in genetic exchanges performed between TYLCV-ES[ES:Mur1:92] and TYLCV-Mld[ES:72:97] to obtain Q1 and Q5; the putative open reading frames (V2, CP, Rep, TrAP, REn, and C4) and the intergenic region (IR) are indicated. B, Hybridization of tissue blots of petiole cross sections of newly emerged young leaves performed at 45 days postinoculation on positively charged nylon membranes (two prints per sample were performed in each individual square); a probe that detects all viruses inoculated was used. Hybridization membranes were exposed to saturation. Plants of tomato cv. 'Moneymaker' were included as susceptible control. Plant number is indicated at the top of the figure. X, means no plant present. 
virus accumulation: $b=0.719$ for $\mathrm{BC}_{1} \mathrm{R}$ and $b=0.713$ for $\left.\mathrm{F}_{2}\right)$ and by departure of uniform and normal distributions $(P<0.001$ for all combinations of traits and populations), which are strong evidences of a genetic control of the resistance by a major locus for traits not completely additive. Accordingly, Wright's minimum number of effective factors (Table 3) was estimated to be around 2 for both traits which suggested a low number of genes controlling resistance. Scaling tests and quantitative gene effects were estimated and the best-fit models are given in Table 3. Significant departure from zero of scaling tests $A$ and $B$ for symptoms and $B$ and $C$ for virus accumulation indicated that adjustment of an $m d h$ additive-dominance model was not possible for the traits. Therefore epistatic interactions were necessary to explain the generation means. Best-fit models for both traits were very similar, with significant additive, dominance, and digenic additive $\times$ additive and dominance $\times$ dominance interactions effects. Greatest effects were those of dominance (positive, that means dominance to more severe symptoms and to higher virus accumulation, i.e., recessive resistance) and of dominance $\times$ dominance epistatic interaction (negative). Broad-sense heritabilities for both traits were fairly high which indicated that breeding for TYLCV resistance from '468-1-1-12' was feasible. Therefore, quantitative genetics

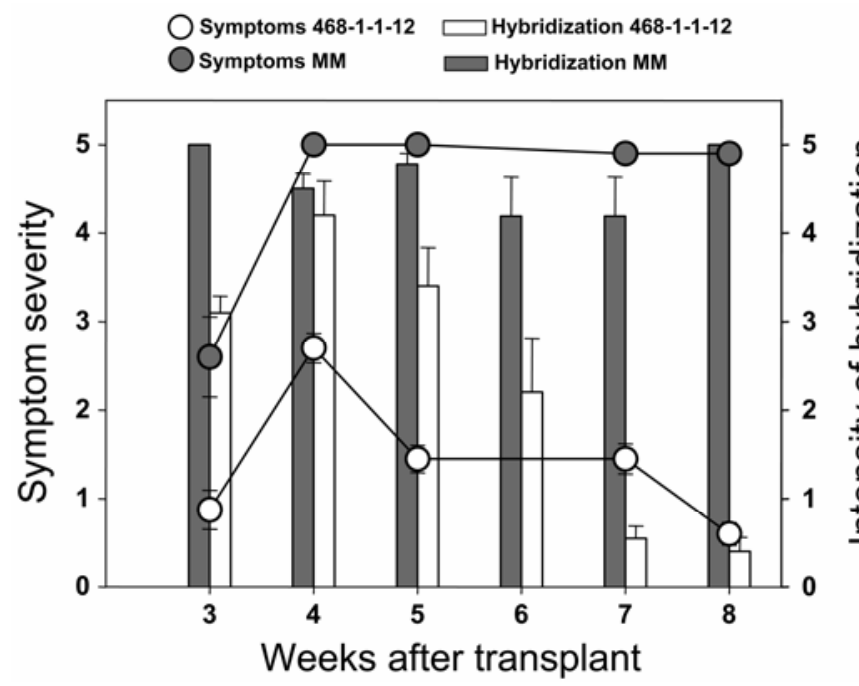

Fig. 4. Time course analysis of symptom severity ( 0 , no symptoms, 5 maximum tomato yellow leaf curl disease symptom severity) and intensity of the hybridization signal ( 0 , no signal, 5 , maximum signal intensity) of tissue blots of petiole cross sections of newly emerged young leaves performed on positively charged nylon membranes for plants of the '468-1-1-12' tomato inbred line naturally infected with tomato yellow leaf curl disease (TYLCD) under field conditions. A probe to TYLCD-associated viruses was used for hybridization. Plants of tomatoes cv. Moneymaker (MM) were included as susceptible control. Results are mean \pm standard error for 20 tomato plants in four replicates for each tomato line. analyses support that resistance in the 'Ohio $8245^{\prime} \times$ ' $468-1-1-12$ ' cross was governed by a major locus with epistatic interactions with at least one minor locus in such a way that, when both loci were in heterozygosis, a reduction in symptoms and virus accumulation appeared because of dominance $\times$ dominance negative effects. Such epistatic effects could explain the tendency to escape from infection observed in $\mathrm{F}_{1}$ plants.

\section{DISCUSSION}

Here we demonstrated that the tomato inbred lines '468-1-112', '483-1-22', and '483-1-30', have resistance to TYLCV. The resistance of these sources expressed as an absence of TYLCD symptoms and a restriction to virus accumulation. Therefore, this resistance likely could be useful to control damage to tomato in many of the TYLCD-affected tomato growing areas because TYLCV is the begomovirus type more widespread worldwide. A similar effective resistant response to TYLCV was already suggested for the original $F_{1}$ hybrid 'Tyking' (53), from which the inbred lines were derived. However, we also demonstrated here that the resistance extends to all major monopartite begomoviruses associated with TYLCD in the Mediterranean area, suggesting a wide range resistance to those viruses. It is noteworthy that previous studies also demonstrated that a tomato line derived from '468-1-1-12', 'TX 468-RG', is a good source of resistance

TABLE 3. Estimates of gene effects $( \pm \mathrm{SE})$, scaling tests $( \pm \mathrm{SE})$, chi-square test of best-fit model adjustment, Wright's minimum number of effective factors $( \pm \mathrm{SE})$, and broad-sense heritability for symptoms and estimated virus accumulation from a six-generation Solanum lycopersicum 'Ohio $8245^{\prime} \times S$. lycopersicum '468-1-1-12' family

\begin{tabular}{lcc}
\hline Genetic parameters $^{\mathrm{b}}$ & Symptoms & Virus accumulation \\
\hline$m$ & $-1.04 \pm 0.41$ & $-1.27 \pm 0.42$ \\
$d$ & $1.65 \pm 0.04$ & $1.15 \pm 0.08$ \\
$h$ & $8.31 \pm 1.02$ & $9.59 \pm 0.97$ \\
$i$ & $2.71 \pm 0.40$ & $4.09 \pm 0.44$ \\
$j$ & $\ldots$ & $\ldots$ \\
$l$ & $-5.61 \pm 0.74$ & $-5.24 \pm 0.72$ \\
$A$ & $1.47 \pm 0.27$ & $0.53 \pm 0.27$ \\
$B$ & $1.38 \pm 0.34$ & $1.21 \pm 0.43$ \\
$C$ & $0.19 \pm 0.55$ & $-2.71 \pm 0.67$ \\
$\chi^{2}$ & $0.080(1 \mathrm{df})$ & $3.641(1 \mathrm{df})$ \\
$P$ & 0.778 & 0.056 \\
$n_{E}$ & $1.9 \pm 0.5$ & $2.3 \pm 0.8$ \\
$H^{2}$ & 0.717 & 0.537 \\
\hline
\end{tabular}

a Plants were inoculated by agroinoculation with TYLCV-IL[ES:Alm:Pep:99] and scored for disease symptoms at 30 days postinoculation and for virus accumulation estimated from intensity of hybridization signal at 15 days postinoculation.

${ }^{\mathrm{b}} m=$ mid-parent value; $d=$ additive effects; $h=$ dominance effects; $i=$ additive $\times$ additive effects; $j=$ additive $\times$ dominance effects; $l=$ dominance $\times$ dominance effects; $A, B, C=$ scaling tests; $n_{E}=$ minimum number of effective factors; and $H^{2}=$ broad-sense heritability.

TABLE 2. Goodness of fit $\left(\chi^{2}\right.$ and $\left.P\right)$ for genetic models of resistance to Tomato yellow leaf curl virus (TYLCV) in a family of generations of a cross between the resistant ' $468-1-1-12$ ' and the susceptible 'Ohio 8245 ' tomato genotypes

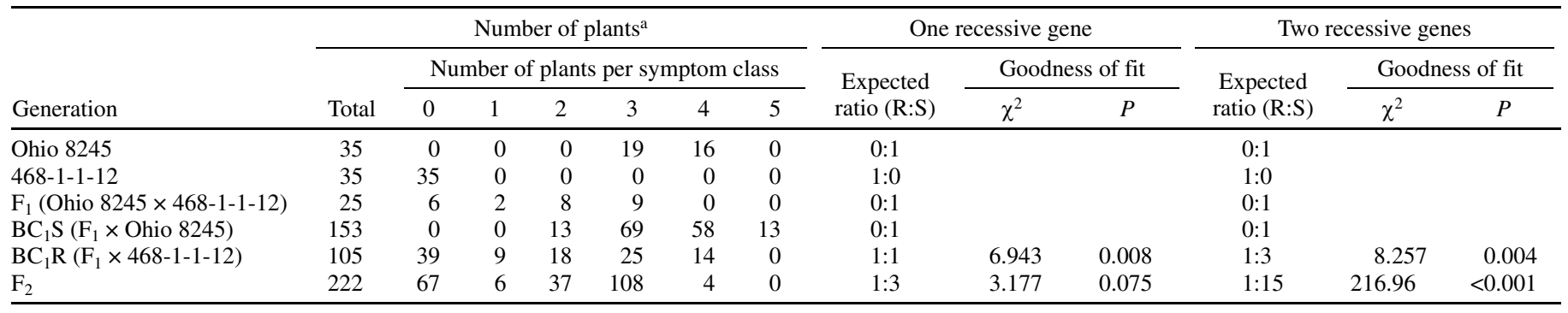

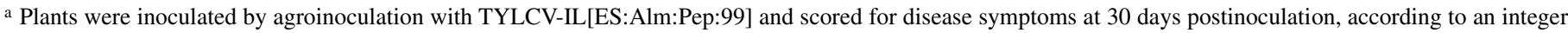
scale from 0 (no symptoms) to 5 (severest symptoms). Resistant $(\mathrm{R})$ plants were those with symptom score $=0$; susceptible $(\mathrm{S})$ plants were those with symptom score $>0$. 
to a range of bipartite begomoviruses infecting tomato in Brazil (65). Therefore, our results strongly emphasize the potential interest of ' $468-1-1-12$ ' and related lines as donors of broad spectrum resistance for begomovirus control in tomato breeding programs.

Evidence was provided for the stability of the resistance described here under extremely high natural TYLCD infection pressure. Interestingly, in these conditions TYLCD symptoms could appear in plants of inbred lines. However, symptoms were much less severe than those observed in plants of the susceptible tomato control, and a recovery from disease and from virus infection occurred in infected resistant plants, suggesting an active host antiviral defense operating in this resistance system. Natural host recovery from viral diseases frequently has been associated with gene silencing mechanisms $(11,12,15)$. Therefore, the resistance described here might be a gene silencing response. In this sense, it should be noted that begomoviruses have been demonstrated to be able to trigger the host silencing machinery leading to recovery from infection (11-13,58). Also, begomoviruses can suppress gene silencing $(5,39,70)$. Therefore, virus infection would depend on the equilibrium between triggering and suppressing gene silencing (35) that in resistant plants might favor a resistance response. Interestingly, it is known that this equilibrium can be influenced by the environmental conditions (13), supporting results observed here, although further studies are needed to determine if gene silencing is involved in this resistance system.

We showed here that differences might exist among TYLCDassociated viruses in their ability to infect '468-1-1-12' resistant plants. This could be related with a differential ability to counteract host plant defense. It is worth mentioning that our results suggest that a virus determinant for the variability between TYLCSV-ES and TYLCV-Mld ability to infect presumably resides in a genome region that comprises part of the Rep and the complete C4 ORFs. Interestingly, there are reports involving the C4 protein with modulation of the defense response $(24,71)$. Therefore, it merits further study to determine the possible involvement of $\mathrm{C} 4$ proteins in the differences observed.

Quantitative genetic analyses suggested that a major recessive locus is controlling the resistance of ' $468-1-1-12$ ' to TYLCV. Recessive traits are frequent in resistance of plants to viruses and have been associated with the lack of factors/functions needed for virus infection $(18,21)$. Therefore, we could hypothesize that the plant host factor needed for an effective interaction of the virus is altered in the resistant inbred lines tested here. In the conditions used, the restriction of TYLCD symptom expression and of virus accumulation appeared to be under the same genetic control, suggesting the traits are closely linked. Quantitative analysis also suggested the involvement of at least one more locus in the resistance and of epistatic interactions between heterozygous loci. The relatively simple mode of inheritance and fairly high heritability described here makes feasible introgression of the resistance from line '468-1-1-12' into tomato commercial varieties. For breeding purposes, it would be of great interest to determine if the major recessive locus found here associated with resistance in '468-1-1-12' to TYLCV coincides with the recessive gene $t \mathrm{~cm}-1$ for resistance to bipartite begomoviruses described in its sister line 'TX 468-RG' (23). For this, $\mathrm{F}_{3}$ progeny families as well as recombinant inbred lines derived from the cross 'Ohio $8245^{\prime} \times$ '468-1-1-12' are under construction and separate inoculations with TYLCV and bipartite begomoviruses are planned.

Recently, Bian et al. (3) reported a tomato breeding line, 'FLA653', which exhibits resistance to the monopartite begomovirus Tomato leaf curl virus. This resistance was demonstrated to be controlled by a single recessive allele (named tgr-1) and was derived by J. W. Scott (University of Florida) from a cross between a susceptible cultivar and a pollen mixture of $S$. chilense 'LA2779' and 'Tyking'. Therefore, it is unknown if the specific source of $\operatorname{tgr}$-1 gene was 'LA2779' or 'Tyking'. 'LA2779' has been shown to contain the $T y-3$ gene for resistance to TYLCV and a resistance allele of $7 y-1$ (27) whilst the resistance source of 'Tyking' is unknown. Interestingly, Bian et al. (3) also demonstrated that 'FLA653' is resistant to isolates of the Sar strain of TYLCSV (29) and of the bipartite begomovirus Tomato leaf curl New Delhi virus (ToLCNDV) (50). However, it remains unclear whether $\operatorname{tg} r$ - 1 also controls the resistance to TYLCSV-Sar and/or to ToLCNDV, and if 'FLA653' is resistant to TYLCV, because this virus was not studied. Moreover, the relationship between tgr- 1 and the recessive allele $t \mathrm{~cm}-1$ reported for bipartite begomovirus resistance from 'TX 468-RG' was not investigated. Therefore, allelism analyses are needed to determine the relationships between $\operatorname{tgr}-1$ and $t \mathrm{~cm}-1$ recessive resistances to bipartite and monopartite begomoviruses and to the major recessive locus for resistance to TYLCV suggested here for line '468-1-1-12'.

The resistance to TYLCD-associated viruses described here is significant because few sources of resistance to TYLCD are available commercially. In fact, the most useful resistance to TYLCD reported to date is provided by the $T y-1$ gene derived from $S$. chilense (38), which is not stable under high disease pressures $(32,38,52)$. This resistance was demonstrated to be controlled by a dominant gene (76), in contrast to the recessive control demonstrated for the resistance described here. Therefore, genetic control might be based on different loci. Then, eventually both resistance traits could be combined for a more efficient TYLCD control. Partial resistance but not immunity (4) to TYLCDassociated viruses was found for the resistance studied here. However, it should be noted that this kind of resistance could be effective reducing virus incidence in nature (48), as restricted virus accumulation in plants might reduce virus availability for vectors, and therefore reduced viral spread (33). Thus, based on our data, a lower risk of TYLCD spread is expected by using the resistance shown here because (i) reduced primary virus spread is expected because of a lower propensity of plants to be infected, and (ii) infected plants accumulate less virus which might help to reduce secondary virus spread. Also, restriction to virus accumulation observed in resistant plants, might determine a reduced selection pressure on the virus population, which can favor the durability of resistance. Therefore, the tomato lines described here could be a valuable source of resistance to TYLCD-associated viruses in addition to bipartite begomoviruses.

\section{ACKNOWLEDGMENTS}

This work was supported by grant AGL2005-03101 of Ministerio de Educación y Ciencia (MEC), Spain (cofinanced by FEDER) and CSIC/ CNPq bilateral action 2005BR0001. R. O. Resende was partially supported by CAPES and MEC in his sabbatical period at the Est. Exp. La Mayora, Consejo Superior de Investigaciones Científicas (CSIC). E. García-Cano completed this research as part of her Ph.D. degree. We thank E. R. Bejarano (Universidad de Málaga, Spain) for providing the infectious clone of TYLCV-IL[ES:Alm:Pep:99], J. E. Polston for helpful discussion and critical reading of the manuscript, and M. V. Martín for technical assistance.

\section{LITERATURE CITED}

1. Accotto, G. P., Navas-Castillo, J., Noris, E., Moriones, E., and Louro, D. 2000. Typing of tomato yellow leaf curl viruses in Europe. Eur. J. Plant Pathol. 106:179-186.

2. Antignus, Y., and Cohen, S. 1994. Complete nucleotide sequence of an infectious clone of a mild isolate of Tomato yellow leaf curl virus (TYLCV). Phytopathology 84:707-712.

3. Bian, X. Y., Thomas, M. R., Rhasheed, M. S., Saeed, M., Hanson, P., De Barro, P. J., and Rezaian, M. 2007. A recessive allele (tgr-1) conditioning tomato resistance to multiple geminiviruses is associated with impaired viral movement. Phytopathology 97:930-937.

4. Birch, R. G. 2001. Disease resistance. Pages 356-364 in: Encyclopedia of Plant Pathology. O. C. Maloy and T. D. Murray, eds. John Wiley \& Sons, Inc., New York. 
5. Bisaro, D. M. 2006. Silencing suppression by geminivirus proteins. Virology 344:158-168.

6. Bjarko, M. E., and Line, R. F. 1988. Heritability and number of genes controlling leaf rust resistance in four cultivars of wheat. Phytopathology 78:457-461.

7. Boiteux, L. S., Oliveira, V. R., Silva, C. H., Makishima, N., Inoue-Nagata, A. K., Fonseca, M. E. N., and Giordano, L. B. 2007. Reaction of tomato hybrids carrying the Ty-1 locus to Brazilian bipartite Begomovirus species. Hortic. Bras. 25:20-23.

8. Brown, J. K., and Bird, J. 1992. Whitefly-transmitted geminiviruses and associated disorders in the Americas and the Caribbean Basin. Plant Dis. 76:220-225.

9. Cahill, M., Gorman, K., Day, S., Denholm, J., Elbert, A., and Naven, R. 1996. Baseline determination and detection of resistance to imidacloprid in Bemisia tabaci (Homoptera: Aleyrodidae). Bull. Entomol. Res. 86:343349

10. Cahill, M., Jarvis, W., Gorman, K., and Denholm, J. 1996. Resolution of baseline responses and documentation of resistance to buprofezin in Bemisia tabaci (Homoptera: Aleyrodidae). Bull. Entomol. Res. 86:117122.

11. Carrillo-Tripp, J., Lozoya-Gloria, E., and Rivera-Bustamante, R. F. 2007. Symptom remission and specific resistance of pepper plants after infection by Pepper golden mosaic virus. Phytopathology 97:51-59.

12. Chellappan, P., Vanitharani, R., and Fauquet, C. M. 2004. Short interfering RNA accumulation correlates with host recovery in DNA virus-infected hosts, and gene silencing targets specific viral sequences. J. Virol. 78:7465-7477.

13. Chellappan, P., Vanitharani, R., Ogbe, F., and Fauquet, C. M. 2005. Effect of temperature on geminivirus-induced RNA silencing in plants. Plant Physiol. 138:1828-1841.

14. Chowda, R. R. V., Colvin, J., Muniyappa, V., and Seal, S. 2005. Diversity and distribution of begomoviruses infecting tomato in India. Arch. Virol. 150:845-867.

15. Covey, S. N., Al-Kaff, N. S., Langara, A., and Turner, D. S. 1997. Plants combat infection by gene silencing. Nature 385:781-782.

16. Czosnek, H., and Laterrot, H. 1997. A worldwide survey of tomato yellow leaf curl viruses. Arch. Virol. 142:1391-1406.

17. de Castro, A. P., Blanca, J. M., Diaz, M. J., and Nuez, F. 2007. Identification of a CAPS marker tightly linked to the tomato yellow leaf curl disease resistance gene Ty-1 in tomato. Eur. J. Plant Pathol. 117:347356.

18. Díaz-Pendón, J. A., Truniger, V., Nieto, C., García-Mas, J., Bendhamane, A., and Aranda, M. A. 2004. Advances in understanding recessive resistance to plant viruses. Mol. Plant Pathol. 5:223-233.

19. Elbert, A., and Nauen, R. 2000. Resistance of Bemisia tabaci (Homoptera:Aleyrodidae) to insecticides in southern Spain with special reference to neonicotinoids. Pest Manag. Sci. 56:60-64.

20. Fauquet, C. M., and Stanley, J. 2005. Revising the way we conceive and name viruses below the species level: A review of geminivirus taxonomy calls for new standardized isolate descriptors. Arch. Virol. 150:21512179

21. Fraser, R. S. S. 1990. The genetics of resistance to plant viruses. Annu. Rev. Phytopathol. 28:179-200.

22. García-Andrés, S., Monci, F., Navas-Castillo, J., and Moriones, E. 2006. Begomovirus genetic diversity in the native plant reservoir Solanum nigrum: evidence for the presence of a new virus species of recombinant nature. Virology 350:433-442.

23. Giordano, L. B., Silva-Lobo, V. L., Santana, F. M., Fonseca, M. E. N., and Boiteux, L. S. 2005. Inheritance of resistance to the bipartite Tomato chlorotic mottle begomovirus derived from Lycopersicon esculentum cv. 'Tyking'. Euphytica 143:27-33.

24. Gopal, P., Pravin Kumar, P., Sinilal, B., Jose, J., Kasin Yadunandam, A., and Usha, R. 2007. Differential roles of C4 and [beta]C1 in mediating suppression of post-transcriptional gene silencing: Evidence for transactivation by the $\mathrm{C} 2$ of Bhendi yellow vein mosaic virus, a monopartite begomovirus. Virus Res. 123:9-18.

25. Griffiths, P. D., and Scott, J. W. 2001. Inheritance and linkage of tomato mottle virus resistance genes derived from Lycopersicon chilense accession LA 1932. J. Am. Soc. Hortic. Sci. 126:462-467.

26. Inoue-Nagata, A. K., Martin, D. P., Boiteux, L. S., Giordano, L. B., Bezerra, I. C., and Ávila, A. C. 2006. New species emergence via recombination among isolates of the Brazilian tomato infecting begomovirus complex. Pesqui. Agropecu. Bras. 41:1329-1332.

27. Ji, Y., and Scott, J. W. 2006. Ty-3, a begomovirus resistance locus linked to $T y-1$ on chromosome 6 of tomato. Tomato Genet. Coop. Rep. 56:22-25

28. Kasrawi, M. A., Suwwan, M. A., and Mansour, A. 1988. Sources of resistance to tomato yellow leaf curl virus in Lycopersicon species. Euphytica 37:61-64.

29. Kheyr-Pour, A., Bendhamane, M., Matzeit, V., Accotto, G. P., Crespi, S., and Gronenborn, B. 1991. Tomato yellow leaf curl virus from Sardinia is a whitefly-transmitted monopartite geminivirus. Nucleic Acids Res. 19:6763-6769.

30. Lande, R. 1981. The minimum number of genes contributing to quantitative variation between and within populations. Genetics 99:541-553.

31. Lapidot, M., Ben Joseph, R., Cohen, L., Machbash, Z., and Levy, D. 2006. Development of a scale for evaluation of Tomato yellow leaf curl virus resistance level in tomato plants. Phytopathology 96:1404-1408.

32. Lapidot, M., and Friedmann, M. 2002. Breeding for resistance to whitefly-transmitted geminiviruses. Ann. Appl. Biol. 140:109-127.

33. Lapidot, M., Friedmann, M., Pilowsky, M., Ben Joseph, R., and Cohen, S. 2001. Effect of host plant resistance to Tomato yellow leaf curl virus on virus acquisition and transmission by its whitefly vector. Phytopathology 91:1209-1213.

34. Laterrot, H. 1995. Breeding network to create tomato varieties resistant to tomato yellow leaf curl virus (TYLCV). Fruits 50:439-444.

35. MacDiarmid, R. 2005. RNA silencing in productive virus infections. Annu. Rev. Phytopathol. 43:523-544.

36. Mather, K., and Jinks, J. L. 1982. Biometrical Genetics. 3rd ed. Chapman and Hall, London.

37. Matos, E. S., Siqueira, W. J., Lourenção, A. L., Melo, A. M. T., Sawazaki, H. E., Souza-Dias, J. A. C., and Colariccio, A. 2003. Resistência de genótipos de tomateiro a um isolado de geminivírus do cinturão verde de Campinas, São Paulo. Fitopatol. Bras. 28:159-165.

38. Michelson, I., Zamir, D., and Czosnek, H. 1994. Accumulation and translocation of tomato yellow leaf curl virus in a Lycopersicon esculentum breeding line containing the L chilense tolerance gene $T y-1$. Phytopathology 84:928-933.

39. Moissiard, G., and Voinnet, O. 2004. Viral suppression of RNA silencing in plants. Mol. Plant Pathol. 5:71-82.

40. Monci, F., Sánchez-Campos, S., Navas-Castillo, J., and Moriones, E. 2002. A natural recombinant between the geminiviruses Tomato yellow leaf curl Sardinia virus and Tomato yellow leaf curl virus exhibits a novel pathogenic phenotype and is becoming prevalent in Spanish populations. Virology 303:317-326

41. Morales, F. J. 2001. Conventional breeding for resistance to Bemisia tabaci- transmitted geminiviruses. Crop Prot. 20:825-834.

42. Morales, F. J., and Anderson, P. K. 2001. The emergence and dissemination of whitefly-transmitted geminiviruses in Latin America. Brief review. Arch. Virol. 146:415-441.

43. Morales, F. J., and Jones, P. G. 2004. The ecology and epidemiology of whitefly-transmitted viruses in Latin America. Virus Res. 100:57-65.

44. Morilla, G., Janssen, D., García-Andrés, S., Moriones, E., Cuadrado, I. M., and Bejarano, E. R. 2005. Pepper (Capsicum annuum) is a dead-end host for Tomato yellow leaf curl virus. Phytopathology 95:1089-1097.

45. Moriones, E., and Navas-Castillo, J. 2000. Tomato yellow leaf curl virus, an emerging virus complex causing epidemics worldwide. Virus Res. $7: 123-134$

46. Navas-Castillo, J., Sánchez-Campos, S., Díaz, J. A., Sáez-Alonso, E., and Moriones, E. 1999. Tomato yellow leaf curl virus-Is causes a novel disease of common bean and severe epidemics in tomato in Spain. Plant Dis. 83:29-32.

47. Navas-Castillo, J., Sánchez-Campos, S., Noris, E., Louro, D., Accotto, G. P., and Moriones, E. 2000. Natural recombination between Tomato yellow leaf curl virus-Is and Tomato leaf curl virus. J. Gen. Virol. 81:2797-2801.

48. Nono-Wondim, R., Gebre-Selassie, K., Palloix, A., Pochard, E., and Marchoux, G. 1993. Study of multiplication of Cucumber mosaic virus in susceptible and resistant Capsicum annuum lines. Ann. Appl. Biol. 122:49-56.

49. Noris, E., Hidalgo, E., Accotto, G. P., and Moriones, E. 1994. High similarity among the Tomato yellow leaf curl virus isolates from the west Mediterranean basin. The nucleotide sequence of an infectious clone from Spain. Arch. Virol. 135:165-170.

50. Padidam, M., Beachy, R. N., and Fauquet, C. M. 1995. Tomato leaf curl geminivirus from India has a bipartite genome and coat protein is not essential for infectivity. J. Gen. Virol. 76:25-35.

51. Peralta, I. E., Knapp, S., and Spooner, D. M. 2005. New species of wild tomatoes (Solanum section Lycopersicon: Solanaceae) from Northern Peru. Syst. Bot. 30:424-434

52. Picó, B., Díez, M. J., and Nuez, F. 1996. Viral diseases causing the greatest economic losses to the tomato crop. 2. The Tomato yellow leaf curl virus. A review. Sci. Hortic-Amsterdam 67:151-196.

53. Picó, B., Díez, M. J., and Nuez, F. 1998. Evaluation of whitefly-mediated inoculation techniques to screen Lycopersicon esculentum and wild relatives for resistance to Tomato yellow leaf curl virus. Euphytica 101:259-271

54. Picó, B., Díez, M. J., and Nuez, F. 1999. Improved diagnostic techniques for tomato yellow leaf curl virus in tomato breeding programs. Plant Dis. 83:1006-1012.

55. Pilowsky, M., and Cohen, S. 1990. Tolerance to tomato yellow leaf curl virus derived from L. peruvianum. Plant Dis. 74:248-250. 
56. Piven, N. M., Uzcátegui, R. C., and Infante, H. D. 1995. Resistance to tomato yellow mosaic virus in species of Lycopersicon. Plant Dis. 79:590594.

57. Polston, J. E., and Anderson, P. K. 1997. The emergence of whiteflytransmitted geminiviruses in tomato in the western hemisphere. Plant Dis. 81:1358-1369.

58. Pooggin, M., Shivaprasad, P. V., Veluthambi, K., and Hohn, T. 2003. RNAi targeting of DNA virus in plants. Nat. Biotechnol. 21:131-132.

59. Rampersad, S. N., and Umaharan, P. 2003. Identification of resistance to Potato yellow mosaic virus-Trinidad isolate (PYMV-TT) among Lycopersicon species. Plant Dis. 87:686-691.

60. Ribeiro, S. G., Ambrozevícius, L. P., Ávila, A. C., Bezerra, I. C., Calegario, R. F., Fernandes, J. J., Lima, M. F., Mello, R. N., Rocha, H., and Zerbini, F. M. 2003. Distribution and genetic diversity of tomatoinfecting begomoviruses in Brazil. Arch. Virol. 148:281-295.

61. Rodríguez-Herrera, R., Rooney, W. L., Rosenow, D. T., and Frederiksen, R. A. 2000. Inheritance of grain mold resistance in grain sorghum without a pigmented testa. Crop Sci. 40:1573-1578.

62. Rybicki, E. P., and Pietersen, G. 1999. Plant virus disease problems in the developing world. Adv. Virus Res. 53:127-175.

63. Sánchez-Campos, S. 2000. El rizado amarillo del tomate en España: Caracterización de los geminivirus implicados y estudio de las epidemias. $\mathrm{PhD}$ thesis, University of Málaga, Spain.

64. Sánchez-Campos, S., Navas-Castillo, J., Camero, R., Soria, C., Diaz, J. A., and Moriones, E. 1999. Displacement of tomato yellow leaf curl virus (TYLCV)-Sr by TYLCV-Is in tomato epidemics in spain. Phytopathology 89:1038-1043.

65. Santana, F. M., Ribeiro, S. G., Moita, A. W., Moreira Júnior, D. J., and Giordano, L. B. 2001. Sources of resistance in Lycopersicon spp. to a bipartite whitefly-transmitted geminivirus from Brazil. Euphytica 122:45-51.

66. Scott, J. W., Stevens, M. R., Barten, J. H. M., Thome, C. R., Polston, J. E., Schuster, D. J., and Serra, C. A. 1996. Introgression of resistance to whitefly-transmitted geminiviruses from Lycopersicon chilense to tomato. Pages 357-377 in: Bemisia: 1995, Taxonomy, Biology, Damage, Control and Management. D. Gerling and R. T. Mayer, eds. Intercept Ltd., Andover, UK.
67. Seal, S. E., van den Bosch, F., and Jeger, M. J. 2006. Factors influencing begomovirus evolution and their increasing global significance: Implications for sustainable control. Crit. Rev. Plant Sci. 25:23-46.

68. Stanley, J., Bisaro, D. M., Briddon, R. W., Brown, J. K., Fauquet, C. M., Harrison, B. D., Rybicki, E. P., and Stenger, D. C. 2005. Geminiviridae. Pages 301-326 in: Virus Taxonomy, VIIIth Report of the ICTV. C. M. Fauquet, M. A. Mayo, J. Maniloff, U. Desselberger, and L. A. Ball, eds. Elsevier/Academic Press, London.

69. Thomas, P. E., and Mink, G. I. 1998. Tomato hybrids with nonspecific immunity to viral and mycoplasma pathogens of potato and tomato. HortScience 33:764-765.

70. Vanitharani, R., Chellappan, P., and Fauquet, C. M. 2005. Geminiviruses and RNA silencing. Trends Plant Sci. 10:144-151.

71. Vanitharani, R., Chellappan, P., Pita, J. S., and Fauquet, C. M. 2004. Differential roles of $\mathrm{AC} 2$ and $\mathrm{AC} 4$ of cassava geminiviruses in mediating synergism and suppression of posttranscriptional gene silencing. J. Virol. 78:9487-9498.

72. Varma, A., and Malathi, V. G. 2003. Emerging geminivirus problems: A serious threat to crop production. Ann. Appl. Biol. 142:145-164.

73. Vidavsky, F., Leviatov, S., Milo, J., Rabinowitch, H. D., Kedar, N., and Czosnek, H., 1998. Response of tolerant breeding lines of tomato, Lycopersicon esculentum, originating from three different sources $(L$. peruvianum, L. pimpinellifolium, and L. chilense) to early controlled inoculation by tomato yellow leaf curl viruses (TYLCV). Plant Breed. 117:165-169.

74. Waterhouse, P. M., Wang, M. B., and Lough, T. 2001. Gene silencing as an adaptive defence against viruses. Nature 411:834-842.

75. Zakay, Y., Navot, N., Zeidan, M., Kedar, N., Rabinowitch, H., Czosnek, H., and Zamir, D. 1991. Screening in Lycopersicon accessions for resistance to Tomato yellow leaf curl virus: Presence of viral DNA and symptom development. Plant Dis. 75:279-281.

76. Zamir, D., Ekstein-Michelson, I., Zakay, Y., Navot, N., Zeidan, M., Sarfatti, M., Eshed, Y., Harel, E., Pleban, T., Van-Oss, H., Kedar, N., Rabinowitch, H. D., and Czosnek, H. 1994. Mapping and introgression of a tomato yellow leaf curl virus (TYLCV) tolerance gene, Ty-1. Theor. Appl. Genet. 88:141-146. 